\title{
How to Study the Slavic Apocrypha in the 21st Century?
}

Case Study: The use of Moses and the Plagues Narratives in the Slavic

Cultures

\author{
Sladjana Mirkovic \\ University of South Florida \\ sladjanamirkovic@yahoo.com
}

\begin{abstract}
This article argues that Rezeptionsgeschichte is an appropriate methodology to study the Slavonic apocrypha in the twenty-first century. This methodology is applied to the reception of the biblical discourse on Moses and the Plagues against the Egyptians, which has been preserved in both ethnic and transnational Slavic textual and material remains that deal with divinized state-founders in the Balkan region.
\end{abstract}

\section{Keywords}

reception history - Slavonic apocrypha - Moses and the plagues on the Egyptians national/transnational identity - folk/ethnic/traditions - hero narrative - state founder - history of religions

While the twentieth century witnessed the suppression of national identity in the strong transnational states in the Balkans, Eastern, and Central Europe, the twenty-first century brings out intense interest in the distinct Slavic literature as the marker of national identity, diminishing thereby its transnational significance and changing its place in the world literature. The need to find the way of how to study Slavic literature in its relationship to religions of Judaism, Christianity, or Islam, as well as to surrounding folk traditions has become pressing. One of the possible ways to cross over the national into transnational significance is the method of Rezeptionsgeschichte ${ }^{1}$ in the sense of diachronic

1 Constance School: H.R. Jauss, Aesthetic Experience and Literary Hermeneutics. Trans. Michael 
and synchronic study of reading, interpretation, refashioning, appropriation, use, and abuse of the tradition and cultural heritage. I refer to the Slavic cultures in a broader sense that implied all aspects of social and cultural life throughout the Late Antiquity since the ninth century down to the present day and included research of the script, language, history, literature, archaeology, fine and applied arts, architecture, music, and cultural traditions of Slavdom. ${ }^{2}$ This article offers an overview of the current state of research by focusing on the Moses and Plagues narrative, and also proposes the trajectory for the future study.

Our case study, the Slavic reception of the Moses and the Plagues on the Egyptians narrative from Exodus 7-12, is a good example of the varieties of the traditions which are represented in this reception. While we examine the literary and social function of Mosaic narratives in Slavic traditions, I propose that we should seek answers to the following questions: Why, how, and for whom in the Slavic cultures did the icon of the divinized Moses embedded in the image of Slavic state founder become important? Why, how, and for whom in the Slavic cultures did the symbol of terrible plagues that produce ethnic cleansing embedded in the liberation wars from the Imperial powers, become so potent?

Previous biblical scholarship focused on separating the reliable from suspected sources about Moses. It treated them often in relative isolation from one other. These sources were usually categorized in artificial groupings, such as biblical and non-biblical, canonical and non-canonical, or literary and material remains. The main problem was that biblical material was studied independently from the "other" literature. "Other" meant suspected, unreliable, and not divinely sanctioned texts. Research on the literary representation of Moses from Heinrich Ewald to Martin Noth, surveyed by Smend, was devoted only to the image of the Biblical Moses. ${ }^{3}$ At the same time, folklorists and an-

Shaw. Minneapolis, 1982; W. Iser, The Act of Reading: A Theory of Aesthetic Response, Baltimore, 1978; Hans-Georg Gadamer, in his book Truth and Method, originally published in 1960, introduces the concept of philosophical hermeneutics.

2 Already in the introduction of her article, Miltenova defines Cyrillo-Methodian mission and traditions in the broader sense that I am using, see in A. Miltenova "The Study of the Cyril and Methodius Mission among the Slavs at the beginning of the 21st century: problems and

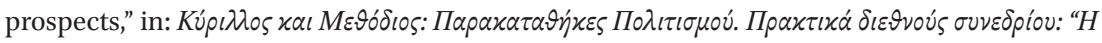

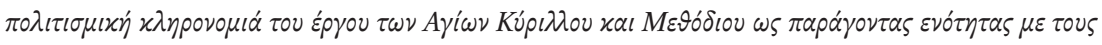

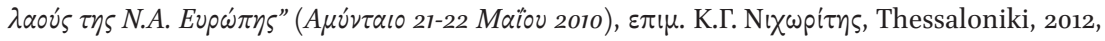
pp. 117-132.

3 R. Smend, Das Mosesbild von Heinrich Ewald bis Martin Noth (Beiträge zur Geschichte der biblischen Exegese, 3) Tübingen, 1959. 
thropologists undertook an extensive research devoted to the hero pattern. ${ }^{4}$ Biblical scholars adopted the hero pattern from them and related it to biblical Mosaic narratives, which was then read as a heroic structure. ${ }^{5}$ Later on, the emphasis shifted to the macrostructure of plague narratives and their theological significance in the Hebrew Bible. ${ }^{6}$ The post-Biblical Moses was overlooked with the exception of the Henri Cazelles's publication in $1977 .{ }^{7}$

More attention was given to the reception of Mosaic narrative in the Rabbinic, early Christian, and in pagan literature. Accordingly, Wayne A. Meeks explored the image of Moses as a prophet and king and its reception in the Rabbinic and non-Rabbinic Jewish literature. ${ }^{8}$ Arthur J. Droge concentrated his research on the image of Moses in early Christian apologetics and the debt of this literature to the earlier Jewish and Greek traditions. ${ }^{9}$ John G. Gager surveyed the portrayals of Moses in pagan authors..$^{10} \mathrm{He}$ asked the question: what did the pagan authors know about Moses and what were their sources? He distinguished among (1) the favorable view of Moses in early Hellenistic writers outside Egypt, (2) the hostile accounts to be found in Egypt and among Roman authors after the Jewish revolts, and (3) the image of Moses as a powerful magician in the Greco-Roman world. Although Gager has devoted two chapters to the Exodus and magic, his primary focus was not Hellenistic Jewish literature.

In the wake of the end of the ww2, the view that Judaism represents a state of mind utterly different from Greco-Roman culture began to break down. It is now widely acknowledged that the Hellenistic period represents a documented stage of the development of Judaism into various groups and the states.

4 R. Segal, "Introduction," in: Quest of the Hero: Otto Rank, Lord Raglan, and Alan Dundes, ed. R. Segal, Princeton, 1990, pp. vii-xxi.

$5 \quad$ The Bible in Human Society: Essays in Honour of John Rogerson, eds. D.J.A. Clines, P.R. Davis, R. Carroll, M. Daniel (Jsots, 200), Sheffield, 1974; J.W. Rogerson, Myth in Old Testament Interpretation (Beihefte zur Zeitschrift für die alttestamentliche Wissenschaft, 134), Berlin-New York, 1974; J.W. Rogerson, Anthropology and the Old Testament: Growing Points in Theology, Atlanta, GA, 1979.

6 B. Childs, The Book of Exodus, Grand Rapids, MI, 1979; R. Rendtorff, The Problem of the Process of Transmission of the Pentateuch (Jsots, 89), Sheffield, 1990.

$7 \quad$ H. Cazelles, "Rédactions et traditions dans l'Exode," in: Studien zum Pentateuch: Walter Kornfeld zum 6o. Geburtstag, hrsg. G. Braulik. Wien, 1977, pp. 37-58.

8 W. Meeks, The Prophet-King: Moses Traditions and the Johannine Christology (Supplements to Novum Testamentum, 14), Leiden, 1967.

9 A.J. Droge, Homer or Moses? Early Christian Interpretations of the History of Culture (Hermeneutische Untersuchungen zur Theologie, 26), Tübingen, 1989.

10 J.G. Gager, Moses in Greco-Roman Paganism (Society of Biblical Literature. Monograph Series, 16), Nashville, 1972. 
Because of the variety of Judaisms, the Hellenistic period has become more intriguing for future research. Building on the shift in the scholarly consensus, Michael Stone ${ }^{11}$ and James Charlesworth ${ }^{12}$ extended the study of Moses to different genera of so called, "Old Testament Pseudepigrapha." This trend resulted in a comprehensive book on the development of Mosaic discourse in the Second Temple Judaism by Hindy Najman. ${ }^{13}$

Also in the post-ww2 years (1945 onwards) in the Eastern and South Eastern Europe, the state-supported universities and institutes promoted and developed the projects of transnational interests only. However, the main questions and debates about the origins, scope, character and traditions of the Slavdom were determined by a largely schematized concepts and interpretations of historical facts rooted in the European historical studies since the seventeenth century. The methods of "national philology," which had contributed immensely to elucidating the cultural heritage of particular language groups, ultimately led to the neglect of general principles and common models of transnational concepts, such as religion. It concerned especially the Orthodox Christian tradition, whose important centuries long role in both the social and literary history of Europe for centuries was downplayed. ${ }^{14}$ The post ww2 Slavic transnational scholarship continued in the same direction developing new transnational models that were not rooted in the historical reality of the traditional Slavdom.

Regarding the Mosaic literature in the Greek language, a significant progress has been made in the area of textual scholarship. John William Wevers completed a major philological study which was published in the Göttingen edition on the Book of Exodus. ${ }^{15}$ Throughout the post-war period the scholarly concern was to place Wisdom of Solomon (1) within the traditions of Hellenistic philosophical and religious thought (2) within the traditions of early Judaism, and (3) to relate Wisdom literature to the Hebrew Bible. Three scholarly traditions have taken different positions with respect to the question of the

11 M.E. Stone, J.C. Greenfield, “The Prayer of Levi,” JBL, 112 (1993), pp. 247-266.

12 J.H. Charlesworth, The Old Testament Pseudoepigrapha. 2 vols. Garden City, NY, 1983-1985.

13 H. Najman, Seconding Sinai: The Development of Mosaic Discourse in Second Temple Judaism (JSJSupp, 77), Leiden-Boston, 2003.

14 In agreement with Miltenova, "The Study of the Cyril and Methodius Mission," pp. 124128.

15 J.W. Wevers, "Einleitung," in:J.W. Wevers, Exodus (Septuaginta. Veturs Testamentum Graecum Auctoritate Academiae Scientarum Gottingensis editum, vol. II, 1), Göttingen, 1991, S. $7-63$. 
sources of Philo's religious thought: (1) the Hellenistic mystery religions, ${ }^{16}(2)$ Jewish sources, ${ }^{17}$ and (3) biblical texts. ${ }^{18}$ The outlines of a more nuanced interpretation of relations between Hellenistic Greek and Jewish culture are demonstrated by Ben Zion Wacholder ${ }^{19}$ on Eupolemos, by Elias Bickerman ${ }^{20}$ on Demetrios and by Howard Jacobson ${ }^{21}$ on Ezekiel.

For the Slavic Mosaic narratives along with other Slavic biblical heritage the Cyrillo-Methodian translation project from Greek into Slavonic has a central role. The work of Cyril and Methodius should be examined within the context of the history of Byzantium's political, diplomatic, ecclesiastical, and cultural relations with the peoples of the Eastern Europe.

While in the past the priorities of Slavic research were often entrapped by ideologies, nowadays the national interests of the Balkan and European cultural heritage are incorporated into the processes of European and Transatlantic integration in the spirit of the principle of "unity in diversity." Since the 1990s, the Slavic studies emerged within the context of the political, diplomatic, ecclesiastical, and cultural relations of Byzantium. Along with cultural anthropological research combining facts from both history and the literary heritage, there have also been innovative studies of the language of translations in the context of the Byzantine-Slavic commonwealth. It seems that a

16 E.R. Goodenough, Jewish Symbols in the Greco-Roman Period, twelve volumes of text and illustrations, plus a thirteenth of indexes, maps and corrigenda published over many years from 1953 to 1968 . An abridged version with the same title was edited by Jacob Neusner (Princeton, 1988), Cf. Religions in Antiquity: Essays in Memory of Erwin Ramsdell Goodenough, ed. J. Neusner, Leiden, 1968.

R. Goulet, La philosophie de Mö̈se: essai de reconstruction d'un commentaire philosophique prephilonien du Pentateuque (Histoire des doctrines de 1'Antiquité classique, 11), Paris, 1987.

18 J.M. Reese, Hellenistic Influence on the Book of Wisdom and Its Consequences (Analecta biblica, 41), Rome, 1970.

19 B.Z. Wacholder, Eupolemos. A Study ofJudeo-Greek Literature (Monographs of the Hebrew Union College, 3), Cincinnati, 1974.

$20 \quad$ E.J. Bickerman, The Jews in the Greek Age, Cambridge, 1988.

$21 \quad$ H. Jacobson, The Exagoge of Ezekiel, Cambridge, 1983; See also his edition of 2009: The Exagoge of Ezekiel, Cambridge, 2009, wherein Jacobson accompanies the text of the play with a translation. In the commentary, he examines the fragments line by line, comparing them with the biblical account and other accounts in related Jewish sources; J.J. Collins, Between Athens and Jerusalem: Jewish Identity in the Hellenistic Diaspora, Crossroad, 1983, p. 224. Here he claims that the work of Ezekiel the Tragedian is another early specimen of mystical Judaism as is found in the drama on the Exodus by Ezekiel, which, at 269 lines, is the most extensive remnant of the Greco-Jewish poets apart from the Sibylline Oracles. 
new age calls for the interdisciplinarity as the saver of Humanities ${ }^{22}$ for $\mathrm{Hu}-$ manities naturally provide the frames of reference for diverse approaches. According to A. Miltenova some of the most salient tendencies in contemporary medieval Slavic Studies are renewed interest in the medieval Slavic translation of the Old Testament that is contextualized in the broader context of Mediterranean culture, involving both ideas and concrete acts within "the Byzantine Commonwealth." ${ }^{23}$ We need to find the way of how to study Slavic literature (and by this I mean both the literature in Old/Church Slavonic and the later ones in individual Slavic languages) in its relationship to surrounding ethnic traditions and autochthonous folk traditions and at the same time in its relation to its religious traditions, namely Christianity, Judaism, or Islam.

The biblical story about the conflict of Moses with Egyptian magicians is preserved in the canonical book of Exodus 7-12. God's will is dramatically demonstrated by ten plagues. Moses, the God's agent, is sent to inform the Pharaoh of the will of God to wrest the people of Israel from the hands of Egypt. The motif of plagues appears also in Pss. 78, 105 (Pss. 77 and 104 in the LXX), and Wisdom of Solomon. In the latter works the number of plagues and their arrangement are different, and the image of Moses fades in the background. The Pesach Haggadah mentions the plagues but does not mention Moses.

If we want to understand these stories, we have to place Mosaic narratives in their matrix of magical nation-buildings and state creations. The storyline provides the model for the miraculous creation of a new language and appropriation of a new religion. Slavic authors following the Hellenistic logic of their Byzantine predecessors did not see the natural world and religious philosophy as mutually exclusive, but as working together in creating a compelling vision of the world and its sacred order. Subsequently, in early period of Slavic cultures there was no neat dividing line between magic, philosophy, and theology. Therefore, Moses the magician gets the promise of magical powers (e.g. mastery of elements, mastery of life and death) and he eventually gains the ability to understand and control the powers of nature. Moses was transformed into a Slavic type hero who possesses scientific knowledge as a gift from God. In the past the text of Pesach Haggadah was defined, on the one hand, as a literature with purely religious purposes, which, according to the dogmatic concept of "literature" that predominated from the 1950s to the 1980s, had no aesthetic

22 Lj. Jovanovic, "Interdisciplinarity as the Lifesaver of Humanities: Manuscripts, Translations, and the Slavic Biblical Heritage," American Public University System, Charles Town, webinar recorded on 06/03/2017.

23 Miltenova, "The Study of the Cyril and Methodius Mission," pp. 120-125. 
value; on the other hand, this type of narrative was a largely uncharted area, since its study required very specialized knowledge.

In order that a researcher conducts a successful study of this corpus of literature, I propose that the following issues should be taken into account:

First of all it is of crucial importance for an interpreter to choose the appropriate method. I am suggesting the method of Rezeptionsgeschichte or reception history because we want to study the reading, interpretation, refashioning, appropriation, use, and abuse of the tradition and cultural heritage over the time and place. Furthermore I believe that the establishment of different stages in reception history of Moses and the Plagues against the Egyptians as the particular discourse in the specific geographical region, in our case the development of Mosaic narrative across the Balkans, is probably the one of better ways to cross over the national into transnational significance of the Mosaic narrative in Slavic garb.

Second, the ancient Slavic documents were produced in, and responded to, a particular social context. The social and ideological tensions in this context provoked Slavic authors to present Mosaic narratives in their own way. Our reading of the sources should be designed to bring to the fore the tensions and relations between various elements of each literary form. Literary sources are an example of cultural creativity and represent a collection of various genres written by different authors over a period of time and place. At the same time, the sources are closely related to one another in a chain of tradition. On closer analysis, they may prove to have a coherent internal system of literary connections, leading to consistent patterns in portraying national and transnational state founders of the Slavic cultures who emulated the magic images of Moses as the liberator, the state founder and the legislator.

Third, the image of Moses in the Plagues discourse needs to be closely explored. The reason for it is that the Slavic artists often chose to embed this image of Moses in the depiction of their historical leaders of the liberation wars. How to define the problem to be investigated? The focus of that work should be the image of Slavic state founder figure who emulates the image of Moses as a diviner in the plague narratives written in the Slavic languages. The ancient stories about Moses as a diviner are based on living traditions to which we have only partial access through texts and other artifacts. The narratives are to be found in different Slavic stories written in old Slavonic and later individual Slavic languages. Our hypothesis should be that any source describing the events in the plague narratives must be, by its nature, an interpretation. They reflect the period of the document's composition and not the time of the events being narrated. Furthermore, these texts represent a reasonably fair insight into the variety of Slavic interpretation of Mosaic narratives. 
In particular, in the plague narratives, Moses was portrayed as a scientist/ wise man, and not as a prophet or the legislator. Early Slavic literature is lavish in its praise of the achievements of their state founders as extraordinary individuals. Early Slavic literature produced and legitimized Moses as a master of cosmological knowledge. Already, in Late Hellenistic Egypt, the rod became the sign of a diviner. Egyptian magic and esoteric knowledge were regarded throughout the Mediterranean world as unmatched. The Slavic world also adopted, appropriated, and reshaped the image of the Hellenistic hero. In the new circumstances the virtues of the hero - the leader of liberation wars and the state founder had to include esoteric as well as scientific and philosophical virtues. Old Slavonic Christian writers created a visible and definable Moses as the holy "wise man" - the state founder.

Finally, the image of the state founder that embeds the Moses as cultural hero par excellence is reintroduced by Slavic writers and artists in the late nineteenth and twentieth century. The twentieth century witnessed the suppression of national identity on account of the strong transnational states such was the case in the Balkans and Central Europe. Slavic artists and writers, in light of their cultural experience, produced portrayals of Moses related to Slavic cultural memory and to the ongoing process of shaping identity by reconstructing the past. State founders in the image of Moses was made the subject of many legends, and lifted to supernatural heights. He became the prototype of a thaumaturgic hero in the Slavic literature. These fantastic stories are a natural production of the historical contact of the Slavs with Greeks and Egyptians.

The liberation struggle of the Slaves from Austro-Hungarian and Ottoman Empire led by future state founder become easily identified with Mosaic discourse of the plagues. That is why the Slavic artists embedded the image of Moses and the plagues against the Egyptians in the imagery of national or transnational figure: However, the 21st century brings out intensive interest in the distinct ethnic literature as the marker of national identity embodied in the rebirth of the images of the nation-state foundational figures or the father of the nation. Does this indicate to the diminishing of its transnational significance and its place in the world literature?

In a larger sense the study on the Moses and the Plagues against Egyptians in the Slavic languages is lacking. In the Slavic cultural and literary sources there is a remarkable presence of the concept that a state founder ought to be like Moses in the Plagues narrative. This view of events and figures serves particular theological or ideological viewpoints, and is not an accurate report of was eigentlich geschehen ist. The comprehensive assessment of the pluralistic development of the Slavonic thought might help us to identify and understand various descriptions of Moses embedded in the state founder imagery. The 
interdisciplinary approach, which takes into account historical, literary, religious, philosophical and scientific perspectives, is the only way to discover these Slavonic/Slavic traditions and to understand the way in which each story about Moses emerged and developed into the imagery of the state founder. While previous scholarship focused on individual authors, we should make a deliberate effort to synthesize similar material on Moses and plague narratives dispersed in Slavic literature. Second, this kind of study should seek to relate the world of magic in the Slavic world as inherited from Late Antiquity to the Mosaic narratives. Previous research maintained a sharp distinction among the areas of myth, magic, religion, and philosophy. Third, the now-traditional ways and preconceptions inherent in early social sciences, comparative Near Eastern studies, and Slavic studies motivated by the apologetic interest regarding the distinctive nature of Jewish religious thought and Slavic national interest need to be supplemented and deepened. Our goal for this research is to uncover social and literary principles and convictions that underlie Slavic views of their state founders who emulate the culture hero Moses, with regard to his image as a diviner.

This kind of project should attempt to produce a survey of the atomized source material about Moses the magician in Slavic literature for the purpose of achieving a broader synthesis. Where relevant, other literature from the ancient Slavonic period should be discussed, as well as inscriptions, papyri or material remains from Slavic lands. One should also discuss related parts of the Mosaic legend that accumulated around the plague narratives and relate them to the Slavic state founders. Finally, we should expect the formation of trajectory that establishes the development of the interpretation of Moses and the Plagues on the Egyptians in the Slavic garb.

The significance of that kind of project lies in advancing our understanding of the Slavic character of Moses and his wonders, miracles and magic in the creation of the state. If we read the ancient Mosaic narratives as social documents, we open whole new vistas for the understanding of the Slavic Moses. This future research could contribute to our understanding of Slavic reception of Moses and the perceptions of Moses in the Balkans. In addition, I believe that the analysis of Moses and the plague narratives might provide an answer to how the Alexandrian interpretation of Moses helped form the cultural identity of, at least, some groups of Balkan Slavs. The end result will be a better understanding of the nature of Christianity in its relationship to Judaism and Islam in the different periods of Slavic history. 